\title{
Cost of diabetes treatment in Mexico
}

\author{
Costo del tratamiento de diabetes en México
}

\author{
Marco Antonio Salinas-Avila ${ }^{a}$
}

\begin{abstract}
:
Diabetes mellitus II (DM II), better known simply as "diabetes", is a chronic disease that occurs when elevated blood glucose levels occur because the body stops producing or does not produce enough insulin, or cannot use it effectively. Currently 6.4 million Mexicans have a medical diagnosis of DM II, that is, $9.4 \%$ of the adult population (20 years and older). However, this figure does not include those who have not been diagnosed or are at high risk of developing the disease. DM II is the second cause of death in Mexico and is among the five leading causes of years of life lived with disabilities. Objective: To describe the cost of Diabetes treatment in Mexico. Materials and Method: A systematic review was carried out on the Internet based on articles published in CROSSREF, PUBMED, JCR, NCBI, SCOPUS, information from government institutions; the search is performed using keywords such as: CostEffectiveness and Diabetes. From a total of 32 reviewed references, 5 (15.5\%) were detected in CROSSREF; 22 (69\%) in PUBMED; $5(15.5 \%)$ were detected from governmental institutions. Results: In 2013, in Mexico, the costs of treatment for DM II were as follows: a) Direct. \$ $179,495.3$ million pesos (1.11\% of GDP) and b) Indirect. \$ 183,364.49 million pesos (1.14\% of GDP). Conclusion: According to the revised literature, the expense that is made in Mexico for diabetes care is high, but most of that investment is going to treat complications and not prevention.
\end{abstract}

\section{Keywords:}

Cost, treatment, Diabetes Mellitus (DMII)

\section{Resumen:}

La diabetes mellitus II (DM II), más conocida simplemente como “diabetes", es una enfermedad crónica que se produce cuando se dan niveles elevados de glucosa en sangre debido a que el organismo deja de producir o no produce suficiente cantidad de la hormona denominada insulina, o no logra utilizar dicha hormona de modo eficaz. Actualmente 6.4 millones de mexicanos tienen un diagnóstico médico de DM II, es decir, el 9.4\% de la población adulta (20 años y más). Sin embargo, esta cifra no incluye a quienes no han sido diagnosticados o están en alto riesgo de desarrollar la enfermedad. La DM II es la segunda causa de muerte en México y está entre las cinco principales causas de años de vida vividos con discapacidad. Objetivo: Describir el costo del tratamiento de Diabetes en México. Material y Método: Se realizó una revisión sistemática en la red de internet en base a artículos publicados en CROSSREF, PUBMED, JCR, NCBI, SCOPUS, información de instituciones gubernamentales; se realizó la búsqueda mediante palabras clave como; Costo-Efectividad y Diabetes. De un total de 32 referencias revisadas, 5 (15.5\%) se detectaron en CROSSREF; 22 (54\%) en PUBMED; 5 (15.5\%) se detectaron de información de instituciones gubernamentales. Resultados: En el 2013 en México los costos del tratamiento para DM II, fueron los siguientes: a) Directos. $\$ 179,495.3$ millones de pesos (1.11\% del PIB) y b) Indirectos. $\$ 183,364.49$ millones de pesos (1.14\% del PIB). Conclusión: De acuerdo a la bibliografía revisada el gasto que se hace en México para la atención de Diabetes es alto, pero la mayor parte de esa inversión se va a tratar las complicaciones y no a la prevención.

\section{Palabras Clave:}

Costo, tratamiento, Diabetes Mellitus (DMII)

\footnotetext{
a Corresponding author, Escuela de Enfermería, Radiología y Bachillerato de Hidalgo. Pachuca, Hidalgo. https://orcid.org/0000-0001-74525975, Email: drmarcoantoniosalinas@ gmail.com
} 


\section{INTRODUCTION}

Diabetes mellitus, better known simply as "diabetes", is a chronic disease that occurs when elevated blood glucose levels occur because the body stops producing or does not produce enough insulin, or cannot use this hormone effectively. ${ }^{1}$

Insulin is an essential hormone, made in an organism gland called the pancreas, which transports glucose from the blood stream to the body's cells, where glucose is converted into energy. The lack of insulin or the inability of the cells to respond to it causes a high level of blood glucose or hyperglycemia, which is the main characteristic of diabetes. Hyperglycemia, if left unchecked, can cause long-term damage to various organs of the body, leading to the development of disabling and lifethreatening health complications such as cardiovascular diseases, neuropathy, nephropathy or eye diseases that end in retinopathy and blindness. On the other hand, if diabetes is managed properly, these serious complications can be delayed or prevented. ${ }^{2}$

According to The American Diabetes Association (ADA) diabetes can be classified into the following general categories:

1. Type 1 diabetes: Caused by autoimmune destruction of B cells, which generally leads to absolute insulin deficiency. ${ }^{3}$

2. Type 2 diabetes: Caused by the progressive loss in insulin secretion of B cells, often generated by insulin resistance. $^{3}$

3. Gestational diabetes mellitus (GDM): diabetes diagnosed in the second or third trimester of pregnancy that was not clearly evident before pregnancy. ${ }^{3}$

4. Specific types of diabetes due to other causes, for example, monogenic diabetes syndromes (such as neonatal diabetes and early onset diabetes of young people [MODY]), diseases of the exocrine pancreas (such as cystic fibrosis and pancreatitis), and diabetes induced by drugs or chemical substances (as with the use of glucocorticoids, in the treatment of HIV/ AIDS, or after organ transplantation). ${ }^{3}$

Around 425 million people worldwide, or $8.8 \%$ of adults aged 20 to 79 , have diabetes. Around $79 \%$ live in low and middle income countries. The number of people with diabetes reaches 451 million if the age is extended to the range of 18 to 99 years. ${ }^{2}$

\section{DEVELOPMENT}

Currently, 6.4 million Mexicans have a medical diagnosis of Diabetes Mellitus II (DMII), that is, $9.4 \%$ of the adult population (20 years and older). However, this figure does not include those who have not been diagnosed or are at high risk of developing the disease. DM II is the second cause of death in Mexico and is among the five leading causes of years of life lived with disabilities. $^{4}$

It is estimated that approximately 4.0 million people between 20 and 79 died of diabetes in 2017, which is equivalent to one death every eight seconds. Diabetes has been responsible for $10.7 \%$ of global mortality from any cause in people of this age group. This figure exceeds the sum of deaths due to the main infectious diseases. $^{5}$

Premature death and disability due to diabetes are also associated with a negative economic impact for countries, which is often defined as "indirect costs" for diabetes. In the US, premature deaths have been estimated to have cost USD 19,000 million to the economy, and a total of USD 69,000 million have been indirectly lost to diabetes. ${ }^{6}$

Since 2006, the International Diabetes Federation (IDF) has included estimates of health spending on diabetes. The evolution has been tremendous, from USD 232,000 million spent by people with diabetes world wide in 2007 to USD 727,000 million in 2015 by people aged 20 to 79 years old (Figure 1). ${ }^{7,8}$

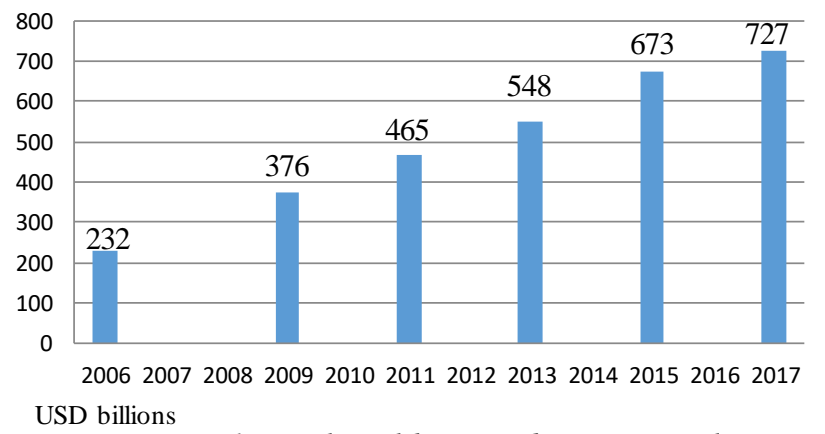

Figure 1. Total Health Expenditure on people with Diabetes in $2017^{7,8}$

Source: Own elaboration

In 2017, the IDF calculates that the total health expenditure on diabetes reached USD 727,000 million (20 to 79 years old), which represents an $8 \%$ increase compared to 2015 calculations. By using the extended age group, 18 to 99 years old, the costs increased to 850,000 million dollars. ${ }^{2}$

In Latin America, it was estimated that more than 41 million people had DM 2015. 97\% lived in Latin America (Central America, South America, Mexico and the Spanish Caribbean) and $2 \%$ in the English Caribbean. ${ }^{9}$

Indirect cost was \$ 57.2 (\$ 54.9-60.4) billion dollars. The total cost of medication was estimated between $\$ 11$ and $\$ 18$ million. This shows how sensitive the cost of coverage is direct, particularly the number of users of insulin or oral medications. The total number of hospitalizations was 36,746 , of which it was 
estimated that more than 18,000 can be attributed to diabetes that causes a burden of more than $\$ 10$ billion. ${ }^{9}$

Regarding the estimates at the national level, and after adjusting the differences according to purchasing power, it was observed that the highest expenses in diabetes come from the United States, with USD 348,000 million, Mexico is in eighth place with USD 19,000 million as it is observed in Figure 2. ${ }^{10}$

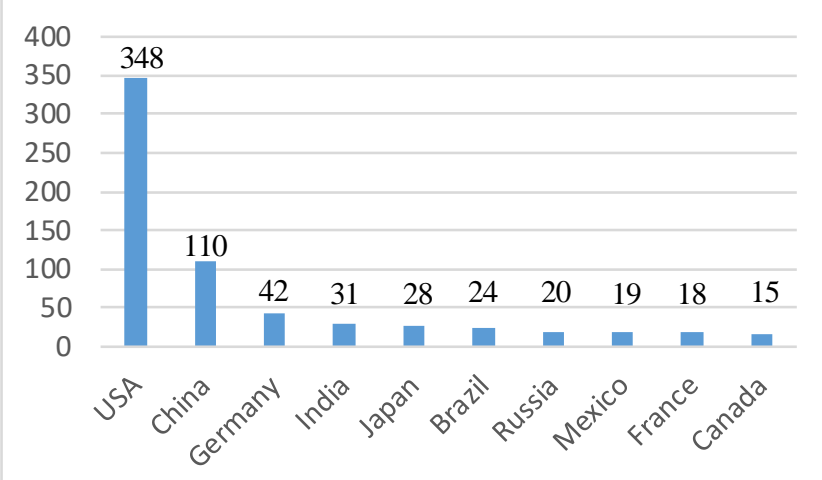

Figure 2. 10 countries with the highest total health expenditure on diabetes in $2017^{10}$

Source: Own elaboration

Public investment in the Mexican Health System has increased from $2.4 \%$ to $3.2 \%$ of gross domestic product (GDP) between 2003 and 2013. However, it is in doubt whether these resources are translated into tangible health benefits. Key indicators suggest that the Mexican Health System is not working as effectively or efficiently as it could. For example, administrative spending represents almost $10 \%$ of the national health budget, the highest in The Organisation for Economic Co-operation and Development (OECD). ${ }^{11}$

The high out-of-pocket health expenditure also indicates a failure of the health system to achieve effective coverage, high quality services, or both. Perhaps as a result of this and other factors, the life expectancy gap between Mexico and other OECD countries has widened from about four years of age to almost six in the last decade. ${ }^{11}$

Therefore, the objective of this article was to describe the cost of diabetes treatment in Mexico.

\section{MATERIALS Y METHOD}

A systematic review was carried out on the Internet based on articles published in CROSSREF, PUBMED, JCR, NCBI, SCOPUS, information from government institutions; the search was performed using keywords such as: cost, treatment and diabetes. Articles and documents that did not cross the three keywords were discarded.

Inclusion criteria: Regarding the temporality of the search, this was carried out with documents issued from the year 2000 , which were articles in English and Spanish languages; this with the purpose of making the information as updated as possible but allowing the obtention of relevant data (cost of treating the disease).

Exclusion criteria. Documents that did not refer to the amounts of direct expenses (consultations, medications, hospitalizations, and complications) and indirect expenses were discarded.

From a total of 32 reviewed references, $5(15.5 \%)$ were detected in CROSSREF; 22 (69\%) in PUBMED; $5(15.5 \%)$ were detected from governmental institutions and the following information was obtained.

\section{RESULTS}

Mexico occupies the sixth place worldwide in the number of people with diabetes, the first place in mortality in Latin America and the third place in the world. ${ }^{12}$

For 2013, the economic burden of diabetes was estimated at $362,859.82$ million pesos, that is, $2.25 \%$ of that year's GDP. This amount is greater than the real annual growth of the Mexican economy registered by INEGI at the end of 2014 (2.1\%), and it is not a small figure compared to the cost of other problems that also constitute barriers to economic development such as corruption, whose cost is estimated at $2 \%-10 \%$ of GDP. ${ }^{12}$

The direct costs of DM II in Mexico were estimated in \$ $179,495.3$ million pesos in 2013, which represents $1.11 \%$ of the Gross Domestic Product (GDP) of that same year. The cost of medical care of the main complications of DM II represents the highest percentage $(87 \%)$ of direct costs.

The indirect costs of DM II in Mexico were estimated at \$ $183,364.49$ million pesos, which represented $1.14 \%$ of the GDP of 2013. The economic loss due to premature death is the one with the greatest weight in these costs $(72.5 \%)$; while the costs associated with the loss of powers to perform a job or any activity that generates income temporarily (work disability) or permanent (disability) or to perform it in a state that is not completely healthy (presentism) have the same weight. ${ }^{13}$

The national average annual cost of case management was $\$ 708$. This represents a differential of the average annual cost by type of institution at a maximum value of $\$ 748$ (annual cost of case management in social security institutions) and a minimum value of $\$ 675$ (annual cost of case management for public assistance institutions for the uninsured.) For every $\$ 100$ pesos spent on diabetes care in Mexico, approximately \$ 51 comes from households/family income. Table 1 shows the breakdown by institution. ${ }^{14,15}$

Table 1 . 


\begin{tabular}{crrrrr}
\multicolumn{7}{c}{ Distribution of direct costs by Institution } & I4,15 & & \\
\hline Institution & $\begin{array}{l}\text { Medical } \\
\text { consultation }\end{array}$ & Medicines & $\begin{array}{l}\text { Hospitaliz } \\
\text { ation }\end{array}$ & $\begin{array}{l}\text { Complicat } \\
\text { ions }\end{array}$ & $\begin{array}{l}\text { Total } \\
\text { CD }\end{array}$ \\
\hline SSA & 71 & 158 & 47 & 131 & 407 \\
IMSS & 160 & 357 & 107 & 296 & 921 \\
ISSSTE & 37 & 83 & 25 & 69 & 215 \\
Users & 310 & 692 & 207 & 574 & 1,748 \\
$\begin{array}{c}\text { Private } \\
\text { Insurance } \\
\text { Total }\end{array}$ & 17 & 39 & 11 & 33 & 102 \\
\hline
\end{tabular}

Figures in MDP (million pesos)

\section{Source: Own Elaboration}

The out-of-pocket expense incurred by people living with diabetes is a matter of seriousness and great concern. Approximately, the out-of-pocket expenditure within the National Health System in Mexico is approximately 50\% (of the highest among OECD countries) so that suffering from diabetes can become a strong financial pressure if the public health system does not meet the basic needs of timely detection, complete diagnosis and comprehensive treatment. ${ }^{16,17}$

\section{DISCUSSION}

DM represents one of the greatest burdens for the Mexican health system, with $90 \%$ of type 2 cases. ${ }^{18-20}$

The purpose of diabetes treatment is to relieve symptoms, maintain metabolic control, prevent acute and chronic complications, improve quality of life and reduce mortality from this disease or its complications. The management plan must include the establishment of treatment goals, nonpharmacological management, drug treatment, patient education, self-monitoring and surveillance of complications. ${ }^{21-}$ 26

As for the direct medical costs for patients with type 2 diabetes, they are high and represent a high economic burden for institutions such as the Instituto Mexicano del Seguro Social (IMSS) that provide these services and medications. Pocket treatments for patients are a high economic burden for the uninsured and insured population, and this is aggravated when it comes to patients earning the minimum wage, since the average annual cost of the treatment is US \$ 196.60 and represents $14.3 \%$ of the patient's annual income of US \$1,377.60. ${ }^{20}$

According to the Clinical Practice Guide, the Pharmacological Treatment of Diabetes Mellitus should be started with Metformin or Acarbose in case of insulin resistance. ${ }^{23,24}$

The most direct economic impact of diabetes is the pressure it generates on the cost of medical care. However, the economic impact goes beyond the finances of the health system. Diabetic patients die prematurely or live day by day with this disease and its complications, which not only determines their demand for health services, but also their ability to work and their level of productivity. This affects the level of family income and the contribution of workers to the production of the country. ${ }^{21}$

The economic burden of a chronic disease encompasses the direct costs associated with spending on medical care (including medical services and medications), and the indirect costs of the disease, that is, those related to the effect of premature mortality and disability of participation of a person in the labor market and its performance in it. The economic burden affects the results that a country has in terms of economic and human development, and the capacity of its workforce, as well as the conditions of equity and poverty. ${ }^{24-26}$

Direct costs refer to the expense in medical care of patients with DM II. This includes the cost of treatment and management of diabetes and its complications. This estimate considers both the public sector perspective, that is, public health institutions, and the private sector perspective. The latter is partially included through private spending -conformed mainly by out-of-pocket household expenses-, associated with outpatient treatment of DM II (medications, outpatient consultations and laboratory tests), and the cost of transportation to attend medical consultations and laboratory tests. In estimating the costs of medical care for complications of DM II, only the public sector perspective is considered. ${ }^{13,27,28}$

Indirect costs refer to the loss of household income as a result of premature death due to DM II, and a lower participation and performance at work as a result of disability ${ }^{13,27,28}$

Low-income households with members with diabetes, Popular Insurance covered a large proportion of these households: this represented a major challenge for that insurance plan and its public providers; and we will have to wait as INSABI will cover those expenses that are produced by vulnerable populations. ${ }^{29}$

The financing of diabetes health services will require the incorporation of clinical, economic and epidemiological indicators, integrating them under the criteria of efficiency. This is due to the fact that there is a problem associated with equity and medical care, since it is of poor accessibility in the different sectors of the Mexican population. ${ }^{30,32}$

In the research aspect, this should focus on the allocation of costs for the types of classification (true positive, true negative, false positive and false negative) in the context of detection of diabetes complications, such as diabetic retinopathy. ${ }^{31,32}$

As diabetes progresses gradually over time, the impact of an intervention has to be modeled taking into account the time, costs and benefits of major complications. ${ }^{32}$

\section{CONCLUSIONS}


In Mexico, approximately 700 dollars are spent annually on patients diagnosed with Diabetes, not counting those that have any complications such as renal failure that would be considered a catastrophic expense.

The Pocket Expenditure of Mexico is $50 \%$ of the total, despite all this, the institutions give most of their budget to address the complications of the disease and not to prevent; making it currently on the brink of an economic crisis.

Mexico has to make a very aggressive strategy in changing lifestyles, as they have done in countries like Chile, in order to reduce the incidence of the disease and thereby reduce the costs of the disease.

\section{REFERENCES}

1. Magliano DJ, Zimmet P, Shaw JE. Classification of diabetes mellitus and other categories of glucose intolerance. In: DeFronzo RA, Ferrannini E, Zimmet P, Alberti G, editors. International Textbook of Diabetes Mellitus. 4th ed. Chichester: Wiley-Blackwell; 2015:3-16.

2. International Diabetes Federation. Complicaciones diabéticas. In International Diabetes Federation, editor. International Diabetes Federation. Diabetes atlas de la FID, 8th ed. Brussels, Belgium: Federación Internacional de Diabetes; 2017: 82-95.

3. American Diabetes Association. Classification and Diagnosis of Diabetes: Standards of Medical Care in Diabetes-2018. Diabetes Care. 2018;4Suppl 1: S13-27.

4. Romero-Martínez M, Shamah-Levy T, Cuevas-Nasu L, Méndez Gómez-Humarán I, Gaona-Pineda EB, Gómez-Acosta LM, et al. Encuesta Nacional de Salud y Nutrición de Medio Camino 2016. Informe final de resultados. Available from: https://ensanut.insp.mx/encuestas/ensanut2016/doctos/informes/ENSA NUT2016ResultadosNacionales.pdf [Accessed 7 February 2020].

5. World Health Organization. Global Health Observatory Data Repository. World Health Organization. Available from: http://apps.who.int/gho/data/?theme=main. [Accessed 3 February 2020].

6. American Diabetes Association. Economic Costs of Diabetes in the U.S. in 2012. Diabetes Care. 2013;36:1033-46.

7. International Diabetes Federation. The Economic Impacts of Diabetes In: International Diabetes Federation, editor. International Diabetes Federation. Diabetes Atlas. 3th ed. Brussels, Belgium: International Diabetes Federation; 2006: 237-266.

8. International Diabetes Federation. The global picture. In: International Diabetes Federation, editor. InternationalDiabetes Federation. Diabetes Atlas. 7th ed. Brussels, Belgium: International Diabetes Federation; 2015: 47-66.

9. Barcelo A, Arredondo A, Gordillo-Tobar A, Segovia1 J, Qiang A. The cost of diabetes in Latin America and the Caribbean in 2015: Evidence for decision and policy makers. J. Glob. Health. 2017;7(2):1-15.

10. Köster I, von Ferber L, Ihle P, Shubert I, Hauner H. The cost burden of diabetes mellitus: the evidence from Germany-the CoDiM Study. Diabetología. 2006; 49:1498-1504.

11. OECD. Service delivery: Defining an equal benefits package and strengthening primary care. In: OECD, editor. OECD Reviews of Health Systems México. Assessment and recommendations 2016. París: OECD Publishing; 2016:91-116.

12. México ¿cómo vamos? Presentación del Semáforo Económico Nacional. Trabajo presentado en la presentación del Semáforo Económico Nacional actua liza do alcierre del 2014, México. Available from:

http://www.mexicocomovamos.mx/wpcontent/uploads/2015/02/Semaf oroNac.pdf. [Accessed 10 February 2020].

13. Funsalud. Estimación de los costos directos de la DM II. In: Funsalud, editor. Carga económica de la diabetes mellitus en México, 2013. México, D.F.: Funsalud; 2015: 20-39.

14. Arredondo-López A, de Icaza-del Río E, Orozco-Núñez A, RecamánMejía AL, Cabrera-López M, Reyes-Sotelo G. Impacto Económico de la Diabetes en México: Deficiencias y Soluciones. En: Aguilar-Salina s CA, Hernández-Jiménez S, Hernández-Ávila M, Hernández Ávila JE, editores. Acciones para enfrentar la Diabetes: Documento de postura. México, D.F.: Intersistemas; 2014: 269-290.

15. Arredondo A, De Icaza E. The cost of diabetes in Latin America: evidence from Mexico. Value Health. 2011;14 5 Suppl 1: S85-8.

16. OECD. Country note: ¿How does health spending in México compare? OECD Health Statistics; 2015. Available from: https://www.oecd.org/els/health-systems/Country-Note-MEXICOOECD-Health-Statistics-2015.pdf [Accessed 15 February 2020].

17. Instituto Nacional de Estadística, Geografía e Información. Principales causas de mortalidad por residencia habitual, grupos de edad y sexo del fallecido. Available from: http://www.inegi.org.mx/est/contenidos/proyectos/registros/vitales/mor talidad/tabulados/Con sultaMortalidad.asp [Accessed 20 February 2020]

18. Secretaria de Salud. NOM-015-SSA2-2010, Para la prevención, tratamiento y control de la diabetes mellitus. Diario Oficial de la Federación, 23 November 2010. Available from: http://www.hgm.salud.gob.mx/descarga s/pdf/dirgral/marco_juridico/n ormas/nom_14.pdf[Accessed 20 February 2020].

19. Córdova-Villa lobos JA, Lee GM, Hernández-Ávila M, Aguilar-Sa lina s CA, Barriguete-Meléndez JA, Kuri-Morales P, et al. Plan de Prevención Clínica de las Enfermedades Crónicas: sobrepeso, riesgo cardiova scular y diabetes mellitus 2007-2012 y Sistema de Indicadores de Diabetes en México. Rev. Mex. Cardiol. 2009;20(1):42-5.

20. Díaz de León-Castañeda C, Altagracia-Martínez M, Kravzov-Jinich J, Cárdenas-Elizalde MdelR, Moreno-Bonett C, Martínez-Núñez JM. Cost-effectiveness study of oral hypoglycemic agents in the treatment of outpatients with type 2 diabetes attending a public primary care clinic in Mexico City. Clinicoecon Outcomes Res. 2012; 4:57-65.

21. Barquera S, Campos-Nonato I, Aguilar-Salinas C, Lopez-Ridaura 1 R, Arredondo A, Rivera-Dommarco J. Diabetes in Mexico: cost and management of diabetes and its complications and challenges for health policy. Global Health. 2013;9(3):1-9.

22. Bloom DE, Cafiero ET, Jané-Llopis E, Abrahams-Gessel S, Bloom L, Fathima S, et al. The Global Economic Burden of Noncommunicable Diseases. Ginebra: Foro Económico Mundial. Available from: http://www3.weforum.org/docs/WEF_Harvard_HE_GlobalEconomicB urdenNonCommunicableDiseases_2011.pdf. [Accessed 18 February 2020]

23. Almeda-Váldes P, García-García E, Aguilar-Salinas CA. Manejo Integral del Paciente con Diabetes Mellitus. In: Aguilar-Salinas CA, Hernández-Jiménez S, Hernández-Ávila M, Hernández Ávila JE, editors. Acciones para enfrentar la Diabetes: Documento de postura. México, D.F.: Intersistemas; 2014: 173-203.

24. Centro Nacional de Excelencia Tecnológica en Salud. Tratamiento de la Diabetes Mellitus tipo 2 en el primer nivel de Atención: Evidencias y Recomendaciones. Catálogo Maestro de Guías de Práctica Clínica: IMSS-718-14. Available from: http://www.cenetec.salud.gob.mx/descargas/gpc/CatalogoMaestro/718 _GPC_Tratamiento_de_diabetes_mellitus_tipo_2_/718GER.pdf. [Accessed 20 February 2020]

25. Nikolic IA, Stanciole AE, Zaydman M. Beyond Health Alone: the Socioeconomic Impact of NCDs. In: Nikolic IA, Stanciole AE, Zaydman M, autors. Chronic Emergency: Why NCDs Matter. Health, Nutrition Population Discussion Paper Washington, DC: World Bank; 2011:7-14. 
26. Arredondo A, Orozco E, alcalde-Rabana J, Navarro J, Azar A. Challenges on the epidemiological and economic burden of diabetes and hypertension in Mexico. Rev. Saúde Pública. 2018;52(23):1-12.

27. Sa las-Zapataa L, Palacio-Mejíab LS, Aracena-Genaoc B, HernándezÁvilad JE, Nieto-Lópeza ES. Costos directos de las hospitalizaciones por diabetes mellitus en el Instituto Mexicano del Seguro Social. Gac. Sanit. 2018;32(3):209-15.

28. Macías-Sánchez A, Villarreal-Páez HJ. Sostenibilidad del gasto público: Cobertura y financiamiento de enfermedades crónicas en México. Ens. Rev. Econ. 2018;37(1):99-134.

29. Gutierrez JP, Garcia-Saiso S, Aracena BM. Mexico's household health expenditure on diabetes and hypertension: What is the additional financialburden? PLoS ONE. 2018:13(7). pii: E0201333.

30. Arredondo A, Reyes G. Health Disparities from Economic Burden of Diabetes in Middle-income Countries: Evidence from México. PLoS ONE. 2013;8(7). pii: E68443.

31. Mendoza-Herrera K, Quezada AD, Pedroza-Tobías A, HernándezAlcaraz C, Fromow-Guerra J, Barquera S. A Diabetic Retinopathy Screening Tool for Low-Income Adults in Mexico. Prev. Chronic Dis. 2017;14. pii: E95.

32. Gilmer T, Burgos JL, Anzaldo-Campos MC, Vargas-Ojeda A. CostEffectiveness of a Technology-Enhanced Diabetes Care Management Program in Mexico. ViHRI. 2019; 20:41-6. 